В. П. Андрющенко

ORCID https://orcid.org/0000-0003-1848-7358 Scopus Author ID 7003989457

В. В. Ващук

ORCID https://orcid.org/0000-0002-0152-0820

ResearcherID G-2453-2019

Scopus Author ID 6701399156

Т. П. Кирик

ORCID https://orcid.org/0000-0002-5263-3841

ResearcherID H-9750-2018

М. I. Кушнірчук

ORCID https://orcid.org/0000-0002-0589-4045

Львівський національний медичний університет імені Данила Галицького

\title{
ДОСВІД ВПРОВАДЖЕННЯ ПРАКТИЧНО ОРІЄНТОВАНОЇ МЕТОДИКИ ВИКЛАДАННЯ ДИСЦИПЛІНИ «ПЕРША МЕДИЧНА ДОПОМОГА 3 ОЗНАЙОМЧОЮ МЕДИЧНОЮ ПРАКТИКОЮ» ДЛЯ СТУДЕНТІВ ФАРМАЦЕВТИЧНОГО ФАКУЛЬТЕТУ
}

\author{
V. P. Andryushchenko, V. V. Vashchuk, T. P. Kyryk, M. I. Kushnirchuk \\ Danylo Halytsky Lviv National Medical University \\ EXPERIENCE OF IMPLEMENTATION OF PRACTICALLY ORIENTED \\ METHODOLOGY FOR TEACHING OF ACADEMIC DISCIPLINE “FIRST \\ AID WITH INTRODUCTORY PRACTICE” FOR STUDENTS OF THE \\ FACULTY OF PHARMACY
}

\begin{abstract}
Анотація. Рання серцево-легенева реанімація та швидка дефібриляція забезпечують виживання пацієнтів при раптовій зупинці кровообігу, а значна частина потерпілих, що потребує невідкладної медичної допомоги, гине через ії̈ несвоєчасність або неадекватність. Відомим є факт, що відсутність допомоги постраждалим протягом першої години після отримання травми збільшує кількість смертельних вислідів на 30 \%, а затримка допомоги понад 3 год завершується летальністю понад 60 \% потерпілих. Саме своєчасність та якість першої долікарської допомоги при різних захворюваннях, травматичних ушкодженнях, нещасних випадках, отруєннях тощо є визначальними для збереження здоров'я і життя потерпілого. Як свідчать результати численних досліджень, проведених під патронатом Всесвітньої організації охорони здоров'я, близько 20 \% загиблих внаслідок травм та нещасних випадків у мирний час могли б бути врятованими за умови вчасного та якісного надання першої долікарської допомоги. Існуюче законодавство в Україні передбачає кримінальне переслідування медичного працівника за ненадання допомоги потерпілому, що перебуває в небезпечному для життя стані. У зв’язку з цим базова серцево-легенева реанімація одна з основних практичних навичок, яку повинен опанувати студент, що здобуває освіту за спеціальністю «Фармація», під час вивчення навчальної дисципліни «Перша долікарська допомога з ознайомчою медичною практикою», підготовки фахівців магістерського рівня. Кожний студент зобов'язаний вміти надавати невідкладну медичну допомогу хворому незалежно від причини виникнення термінального стану, на основі сучасних стандартів та міжнародних протоколів. На сьогодні в царині реаніматології існує вагома доказова база щодо проведення серцево-легеневої реанімації, на яку, безумовно, необхідно спиратися в процесі навчання студентів фармацевтичного факультету.
\end{abstract}

Ключові слова: серцево-легенева реанімація; навчання; студенти-фармацевти.

Abstract. Cardiopulmonary resuscitation and defibrillation, initiated in time, ensure the survival of patients with sudden cardiac arrest and respiration. Most victims in need of emergency medical care may die when emergency medical care is provided incorrectly and late. When emergency care is provided to victims within the first hour after injury, it increases the number of patients who die by $30 \%$. If the aid is delayed for 3 hours or more, it leads to the death of more than $60 \%$ of victims. First aid, which resuscitators perform in a quality and timely manner for various serious diseases, traumatic injuries, accidents, poisonings, is very important for maintaining the health and lives of victims. According to many studies conducted under the auspices of the World Health Organization, about

(C) В. П. Андрющенко, В. В. Ващук, Т. П. Кирик, М. І. Кушнірчук 
$20 \%$ of deaths from injuries and accidents in peacetime can be saved. This requires timely and high-quality first aid. Laws in Ukraine provide for criminal liability of a medical worker or resuscitator for failure to provide assistance to a victim who is in a life-threatening condition. Basic cardiopulmonary resuscitation is one of the basic practical skills that a student majoring in Pharmacy should know. Basic cardiopulmonary resuscitation and automatic defibrillation are studied by students during the course "First aid with introductory medical practice”. This is the level of training of master's level specialists. Every student must be able to provide emergency medical care to the patient, regardless of the cause of the terminal condition, based on modern standards and international protocols. Today, in the field of resuscitation, there is a strong evidence base for cardiopulmonary resuscitation, which, of course, must be relied on in the teaching process of students of the Faculty of Pharmacy.

Key words: cardiopulmonary resuscitation; training; pharmacist student.

Вступ. Важливе завдання медичної освіти - навчання студента методів кваліфікованої медичної допомоги при невідкладних і критичних станах. Одним із розділів навчання $є$ формування навичок проведення базової серцево-легеневої реанімації (BLS) при зупинці серця із застосуванням симуляційних технологій, що є передовою формою засвоєння матеріалу, і вимагає індивідуального підходу при проведенні занять, тому що при відтворенні практичних навичок у студентів часто виникають хвилювання, почуття страху та невпевненості у своїх знаннях [3, 6, 7]. Ці фактори значною мірою впливають на кінцевий результат навчання. Слід зазначити, що зупинка серцевої діяльності $€$ критичною ситуацією не тільки для пацієнта, але й для лікаря, який надає допомогу. Успіх реанімації залежить від багатьох чинників: кваліфікації та характерологічних особливостей лікаря, його знань алгоритму проведення серцево-легеневої реанімації (СЛР), вміння якісно проводити компресії грудної клітки і штучне дихання. Не кожен фахівець може повноцінно провести СЛР, навіть якщо у нього є достатні теоретичні знання. Станом на сьогодні в Україні перша долікарська допомога (ПДД) до прибуття бригади невідкладного реагування практично не надається, тим самим у багатьох випадках суттєво зменшуються шанси постраждалого на виживання. Як свідчить практика, окрім відсутності медичної освіти та базових знань із рятування людей, другою за рахунком причиною, чому люди не намагаються врятувати інше життя, $є$ страх юридичних наслідків та кримінальна відповідальність у випадку негативних вислідів ПДД. Після подій 2013-2014 рр. в Україні значно зросло число осіб, які пройшли курси із надання ПДД та володіють навичками СЛР. Але навіть маючи відповідні знання, чимало осіб зупиняється з огляду на юридичні аспекти, адже свідомість людини у першу чергу в будь-якій ситуації спрямована на власну безпеку. Всесвітня організація охорони здоров’я рекомендує звільняти від відповідальності осіб, які надають допомогу постраждалому, аби стимулювати та збільшити мотивацію на проведен- ня невідкладних заходів. У більшості розвинутих країнах діє законодавча база, яка регулює право на надання ПДД та правовий статус особи, котра таку допомогу здійснює. Головна умова закону постраждалий не може подати позов за неправильно надану ПДД, якщо вона надавалася сумлінно, 3 найкращих міркувань та без очікування можливої компенсації [2, 4].

Мета дослідження - проаналізувати досвід впровадження єдиного стандарту викладання алгоритму BLS студентам фармацевтичного факультету під час вивчення дисципліни «Перша долікарська допомога з ознайомчою медичною практикою» на кафедрі загальної хірургії Львівського національного медичного університету імені Данила Галицького.

Методи дослідження. Практично-орієнтований курс з елементами симуляції по BLS проходив дворічну апробацію з охоплення студентів 3 курсу фармацевтичного факультету. Навчання при проходженні вказаної тематики включало лекції, освоєння алгоритму надання допомоги при раптовій зупинці серця і практичні заняття на манекенах. Загальна тривалість тематики складає 6 академічних годин. 3 метою порівняльного аналізу в дослідження були залучені показники успішності студентів цього ж факультету за більш ранній період.

Результати дослідження. Аналіз успішності студентів по темах дисципліни, присвячених вивченню BLS, за період 2017-2018 навчальних років (охоплено 2 послідовних курси) показав, що не всі студенти оволоділи даними навичками повною мірою, а оцінювання здобутих компетенцій, з боку викладачів, інколи мало суб'єктивний характер. Не виключалася можливість упущення контролю одного з етапів виконання навички або ж домінування впливу одного з чинників на кінцеву оцінку освоєння тематики BLS. Незважаючи на достатній рівень теоретичної підготовки та надані пояснення викладача, студенти зазначили, що перед демонстрацією практичної навички відчували почуття страху, невпевненості у своїх знаннях та сорому перед колегами. Перші спроби практичного відтворення навичок були успішними лише у 25 \% 
студентів, для решти демонстрація виявилася невдалою. Ефективній роботі перешкоджали хвилювання і розгубленість, а також нездатність утримати в пам’яті алгоритм дій.

3 метою впровадження уніфікованих підходів і підвищення якості у формуванні практичної навички на кафедрі було проведено низку організаційно-методичних заходів. Зокрема, був розроблений єдиний стандарт виконання практичної навички та встановлені уніфіковані критерії оцінювання засвоєння виконання етапів BLS. За основу методологічної розробки тематики був прийнятий сертифікований курс BLS американської асоціації (АНА), стандарту 2016 р. в авторській модифікації технології викладання. Теоретична частина містила лекцію, в якій покроково обговорювався кожен елемент алгоритму BLS. Даний етап спрямований на формування уявлення про сучасні підходи до алгоритму BLS i, презентує, наукове обгрунтування всіх дій рятувальника в екстремальних ситуаціях. Практичне навчання здійснювалося на спеціалізованих тренажерах із використанням такого обладнання, як: манекени «Mini Baby CPR» та «Mini Anne CPR», набори масок і клапанів для CЛP, мішок Амбу, універсальний тренажер AED WL120ES10 з блоком програмування ситуацій $[1,5]$.

Навчання мало симуляційний характер і проводилося за таким алгоритмом: 1. Спочатку викладач без пояснень показує весь комплекс BLS, 3 метою формування на першому етапі загального уявлення про правильне виконання навички. Важливим фактором є досконале володіння викладачем усіма елементами BLS (непрямий масаж серця, штучне дихання), і недопущення помилок під час демонстрації. Оскільки студенти можуть на підсвідомому рівні запам’ятовувати недоліки i, в майбутньому, повторювати їх. 2. Викладач на практиці повторює весь алгоритм виконання BLS, але вже з докладним поясненням кожної своєї дії, наприклад: «нахиляюся до рота потерпілого і, протягом 10 секунд, визначаю наявність дихальних шумів». Це необхідно для того, щоб не упустити жодних моментів у процесі пояснення алгоритму, окрім того, такий підхід дозволяє студентам 3 точністю засвоювати і повторювати дії викладача. 3. Викладач повторно проводить BLS, але вже під вказівки студентів, наприклад виголошується вказівка: «Підійдіть до потерпілого та запитайте у нього, чи потрібна допомога». Таким чином, студенти проговорюють алгоритм, який сприяє кращому засвоєнню матеріалу. 4. Питання та обговорення.
Після того як студенти отримали повну інформацію про BLS, вони отримують змогу ставити питання викладачеві. 5. Далі студенти по черзі проводять весь комплекс BLS із наступним обговоренням дій кожного студента. При цьому, спочатку, відзначаються позитивні моменти, потім - недоліки. Участь викладача полягає в детальному аналізі з кожним студентом всіх його помилок та недоліків. 6. Студенти повторно виконуть алгоритм BLS з урахуванням виявлених та проаналізованих раніше недоліків. 7. Викладач демонструє виконання алгоритму BLS у складі бригади з двох реаніматологів. Робота в парі пов’язана з певними особливостями (розташування рятувальників щодо потерпілого та один до одного, розподілу функцій тощо). 8. Виконання студентам алгоритму BLS у парах. 9. Фінальне обговорення алгоритму BLS. Студенти отримують можливість ставити питання та обговорити спірні моменти. 10. Проведення заліку в індивідуальному порядку з наступним обговоренням результатів та роз'ясненням помилок, за їх наявності.

Інтеграція вказаної методики в навчальний процес студентів 3-го курсу фармацевтичного факультету, починаючи з 2019 навчального року, забезпечила уніфікацію викладання даних навичок на всіх етапах вивчення теми, що, у свою чергу, підвищило якість засвоєння матеріалу та покращило об’ єктивність оцінювання студентів. Детальне багаторазове пояснення викладача, зосередження на діях і реалістичне моделювання ситуації сприяли тому, що застосування наведеної методики суттєво покращило успішність студентів. Так, у фіналі курсу, близько 95 \% студентів впоралися з почуттям страху та невпевненості у своїх діях. Цьому сприяли неодноразові повторення алгоритму проведення BLS, хороша і доброзичлива атмосфера під час проведення занять. У результаті проходження курсу BLS всі студенти освоїли необхідний об’ єм практичних навичок: компресії грудної клітки, штучне дихання, використання дистанційних засобів індивідуального захисту, застосування автоматичного дефібрилятора, вкладання потерпілого в безпечне положення тощо. Також важливим моментом $є$ оцінка організації навчання і роботи викладача з боку студентів. Майже всі учасники висловили задоволення рівнем викладацької майстерності викладачів. На думку студентів, досягнення успіху в навчанні забезпечувалося хорошою організацією занять, достатнім рівнем апаратного забезпечення, моделлю навчання, доступним викладом матеріалу та індивідуальним підходом до кожного учасника. 
Висновки та перспективи подальших досліджень. Проведення практично-орієнтованих занять у студентів фармацевтичного факультету за тематикою базової серцево-легеневої реанімації та автоматичної зовнішньої дефібриляції є важливим етапом навчання, що сприяє набуттю теоретичних знань і практичних навичок при раптовій зупинці серця. Впровадження запропонованого алгоритму створює передумови для формування доброзичливої атмосфери, індивідуального підходу до кожного студента і забезпечує подолання хвилювання та не-

\section{Список літератури}

1. Craig-Brangan. Update: 2015 AHA BLS and ACLS guidelines / Craig-Brangan, Karen Jean, Mary Patricia Day // Nursing2019 Critical Care. - 2016. - Vol. 11, No. 3. P. 24-29.

2. Early cardiopulmonary resuscitation in out-of-hospital cardiac arrest / I. Hasselqvist-Ax, G. Riva, J. Herlitz [et al.] // New England Journal of Medicine. - 2015. - Vol. 372, No. 24. - P. 2307-2315.

3. Lockey A. Impact of adult advanced cardiac life support course participation on patient outcomes - a systematic review and meta-analysis / A. Lockey, Y. Lin, A. Cheng // Resuscitation. - 2018. - Vol. 129. - P. 48-54.

4. National initiatives to improve outcomes from outof-hospital cardiac arrest in England / [G. D. Perkins, A. S. Lockey, M. A. de Belder et al.]. - 2016.

\section{References}

1. Craig-Brangan, K.J., \& Day, M.P. (2016). Update: 2015 AHA BLS and ACLS guidelines. Nursing2019 Critical Care, 11 (2), 24-29.

2. Hasselqvist-Ax, I., Riva, G., Herlitz, J., Rosenqvist, M., Hollenberg, J., Nordberg, P., ... \& Karlsson, T. (2015). Early cardiopulmonary resuscitation in out-of-hospital cardiac arrest. New England Journal of Medicine, 372 (24), 2307-2315.

3. Lockey, A., Lin, Y., \& Cheng, A. (2018). Impact of adult advanced cardiac life support course participation on patient outcomes - a systematic review and metaanalysis. Resuscitation, 129, 48-54.

4. Perkins, G.D., Lockey, A.S., de Belder, M.A., Moore, F., Weissberg, P., \& Gray, H. (2016). National initiatives to improve outcomes from out-of-hospital cardiac arrest in England. впевненості у своїх діях. Для проведення навчання найбільш оптимальними є групи до 10 студентів, що дозволяє ефективно провести заняття і досягти кінцевого результату навчання.

Представлені результати досліджень є початковою ланкою визначення ефективності та доцільності проведення практично-орієнтованих занять у студентів фармацевтичного факультету за тематикою базової серцево-легеневої реанімації і потребують подальшого аналізу опанування практичних навичок із зазначеної тематики.

5. Part 7: adult advanced cardiovascular life support: 2015 American Heart Association guidelines update for cardiopulmonary resuscitation and emergency cardiovascular care / M. S. Link, L. C. Berkow, P. J. Kudenchuk [et al.] // Circulation. - 2015. - Vol. 132, No. 18 (Suppl. 2). - P. S444S464.

6. Part 8: Education, implementation, and teams: 2015 International consensus on cardiopulmonary resuscitation and emergency cardiovascular care science with treatment recommendations / J. C. Finn, F. Bhanji, A. Lockey [et al.]// Resuscitation. - 2015. - P. e 203.

7. The system-wide effect of real-time audiovisual feedback and postevent debriefing for in-hospital cardiac arrest: the cardiopulmonary resuscitation quality improvement initiative / K. Couper, P. K. Kimani, B. S. Abella [et al.] // Critical Care Medicine. - 2015. - Vol. 43, No. 11. - P. 2321.

5. Link, M.S., Berkow, L.C., Kudenchuk, P.J., Halperin, H.R., Hess, E.P., Moitra, V.K., ... \& White, R.D. (2015). Part 7: adult advanced cardiovascular life support: 2015 American Heart Association guidelines update for cardiopulmonary resuscitation and emergency cardiovascular care. Circulation, 132, 18 (2), S444-S464.

6. Finn, J. C., Bhanji, F., Lockey, A., Monsieurs, K., Frengley, R., Iwami, T., ... \& Greif, R. (2015). Part 8: Education, implementation, and teams: 2015 International consensus on cardiopulmonary resuscitation and emergency cardiovascular care science with treatment recommendations. Resuscitation, 95, e203.

7. Couper, K., Kimani, P.K., \& Abella, B.S. (2015). The system-wide effect of real-time audiovisual feedback and postevent debriefing for in-hospital cardiac arrest: the cardiopulmonary resuscitation quality improvement initiative. Critical Care Medicine, 43 (11), 2321. 